Hans Günter Brauch Patricia Kameri-Mbote

Úrsula Oswald Spring Béchir Chourou

Czeslaw Mesjasz

John Grin

Pál Dunay

Jörn Birkmann

(Eds.)

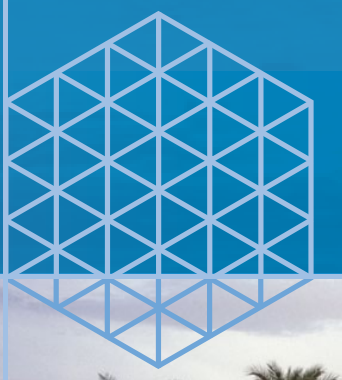

VOL 5 / HEXAGON SERIES ON HUMAN AND ENVIRONMENTAL SECURITY AND PEACE

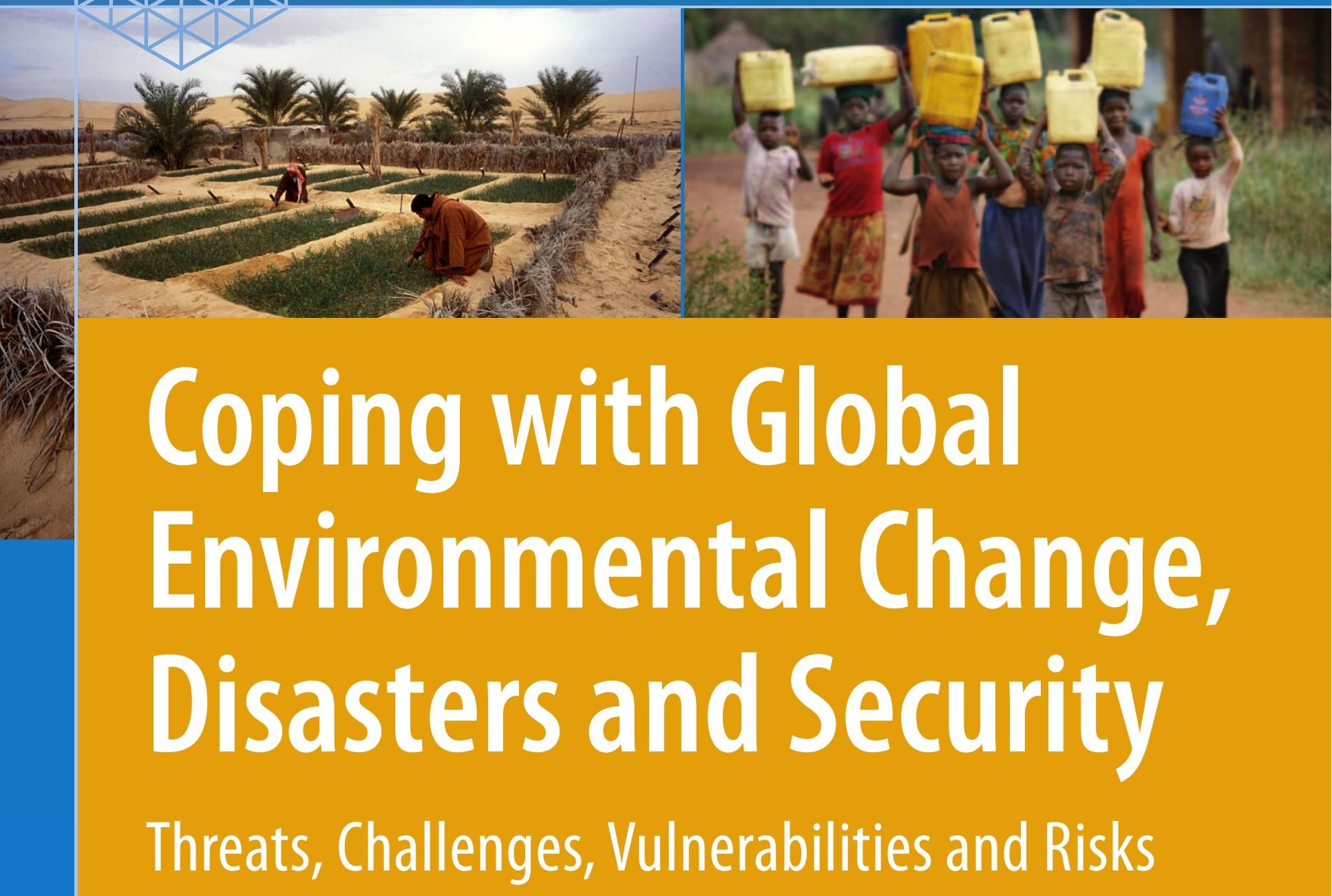

Threats, Challenges, Vulnerabilities and Risks

Springer 
Part I Introduction: Concepts of Security Threats, Challenges, Vulnerabilities and Risks

1 Introduction: Coping with Global Environmental Change in the Anthropocene

Hans Günter Brauch and Úrsula Oswald Spring

2 Concepts of Security Threats, Challenges, Vulnerabilities and Risks

61 Hans Günter Brauch

3 Disaster Risk and Vulnerability: Concepts and Measurement of Human and Environmental Insecurity Omar D. Cardona

$4 \quad$ Economic Vulnerability and Economic Security Czeslaw Mesjasz

5 Debt Relief, Economic Growth and Poverty Reduction in Low-Income Countries Lidia Mesjasz

\section{Part III Securitization of Global Environmental Change}

Alyson J.K. Bailes

NATO's Traditional Security Problems

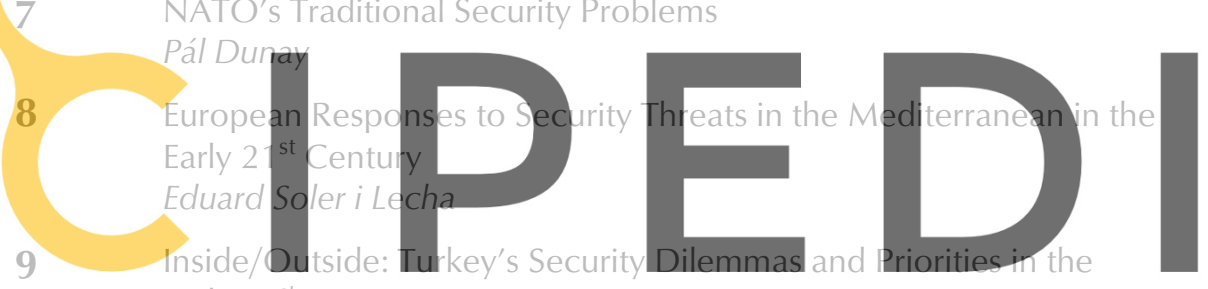

10 Promoting Democracy as a Security Goal. The 'inward-outward' Paradox of the EU's Foreign Policy

Omar Serrano

11 Language Games on Security in Finland: Towards Changing Concepts of the State and National Survival

Vilho Harle and Sami Moisio

12 Security Threats, Challenges, Vulnerabilities and Risks in US National Security Documents (1990-2010)

Hans Günter Brauch

13 Changes in the Perception of Military Threats, Challenges, Vulnerabilities and Risks in Russia (1991-2009)

Alexander Sergunin

14 Russian Security Policy in the $21^{\text {st }}$ Century Based on the Experiences of Its First Decade Pál Dunay 
15 Non-Traditional Security and the New Concept of Security of China Zhongqin Zhao

16 Perceptions of Hard Security Issues in the Arab World Gamal M. Selim

17 Arab Perceptions of Soft Security Issues Mohammad El-Sayed Selim

18 Military Challenges and Threats in West Africa Kwesi Aning and Andrews Atta-Asamoah

19 Weak States and Security Threats in West Africa John Emeka Akude

Part III Economic, Social, Environmental Security and Human Threats, Challenges, Vulnerabilities and Risks in the Near East, North and Sub-Sahara Africa and in Asia

20 Environmental Challenges and Risks in North Africa

\section{Béchir Chourou}

$21 \quad$ Water Degradation as a Human Security Challenge in Jordan

\section{Bassam Ossama Hayek and Nisreen Daifallah Al Hmoud}

Water Scarcity and Degradation in Palestine as Challenges,

Vulnerabilities, and Risks for Environmental Security

Marwan Haddad
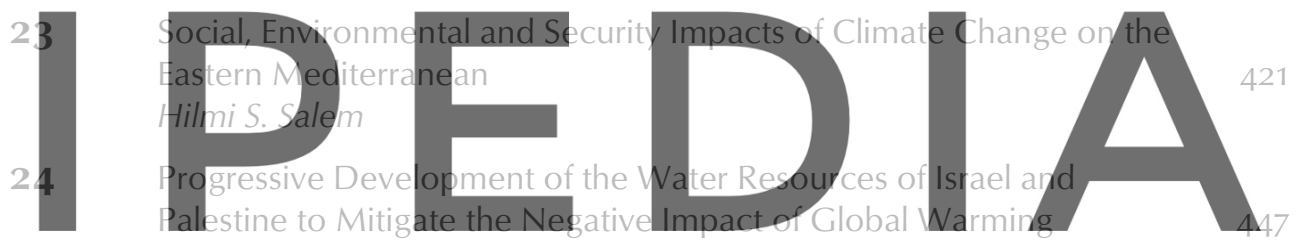

Arie S. Issar

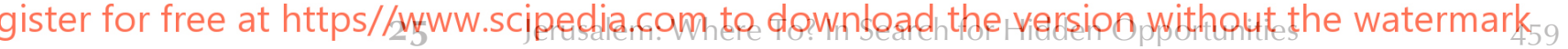
Mohammed S. Dajani Daoudi and Ashraf M. Dajani

26 Global Climate Change Impacts for the Mediterranean in the $21^{\text {st }}$ Century: Challenges for Human and Environmental Security Hans Günter Brauch

27 Global Environmental Change and Conflict Potential in Central Asia

Jenniver Sehring and Ernst Giese

28 Impact of Environmental Change on Stability and Conflict Potentials in China

Thomas Heberer and Anja D. Senz 
Part IV Threats, Challenges, Vulnerabilities and Risks for Urban Centres in Hazards and Disasters

29 The Vulnerability of Cities to Disasters and Climate Change:

A Conceptual Framework

Mark Pelling

30 Vulnerability to Natural Hazards: Case Study on Landslide Risks in La Paz

Fabien Nathan

31 Revealing the Impact of Small Disasters to the Economic and Social Development Mabel C. Marulanda, Omar D. Cardona and Alex H. Barbat

32 Climate Change, Natural Hazards and Coastal Ecosystems in Latin-America: A Framework for Analysis Carmen Lacambra and Kaveh Zahedi

33 Flood Loss Redistribution in a Third World Megacity:

The Case of Mumbai

603

Monalisa Chatterjee

34 Coping with Water- and Wastewater-related Risks in Megacity Delhi Reena Singh

35 Politics of Displacement and Vulnerability Nanda Kishor

Linking Oriental and Western Thinking to Mitigate Flood Risk
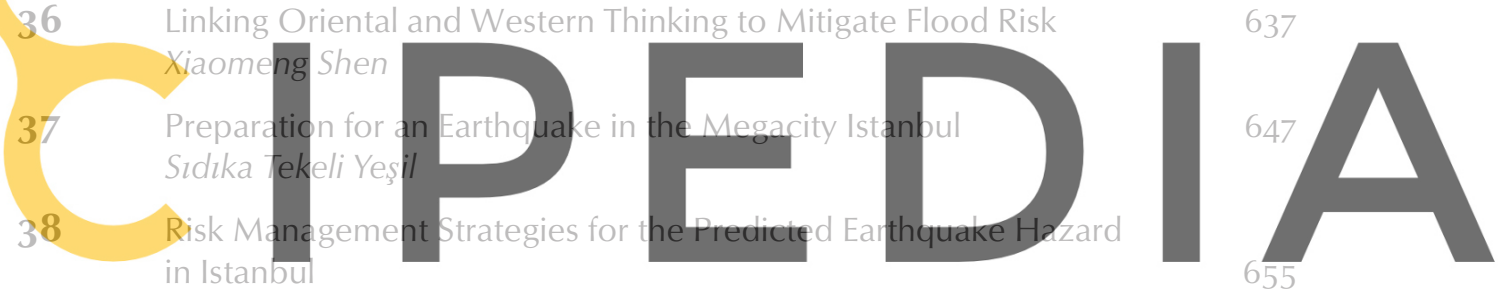

Fbru A Gencer

gister for free at https//www.scipedia.com to download the version without the watermark

$39 \quad$ Urban Vulnerability to Climate Change and Natural Hazards in Nigeria 669

Adeniyi Sulaiman Gbadegesin, Felix Bayode Olorunfemi and

Usman Adebimpe Raheem

Part V Coping with Global Environmental Change: Climate Change, Soil and Desertification, Water Management, Food and Health

40 Quantifying Global Environmental Change Impacts: Methods, Criteria and Definitions for Compiling Data on Hydro-meteorological Disasters Debarati Guha-Sapir and Femke Vos

\section{Section A: Climate Change}

$41 \quad$ Stormy Weather: International Security in the Shadow of Climate Change 
42 Security Risks of Climate Change: Vulnerabilities, Threats, Conflicts and Strategies Jürgen Scheffran

43 New Threats? Risk and Securitization Theory on Climate Change and Water

Anders Jägerskog

44 Dealing With Uncertainties in Climate Change Impacts Assessments:

A Case Study on the Nile Basin

Carlo Buontempo, Jens Kristian Lørup, Michael Sanderson, Michael Butts,

Erika Palin, Rachel McCarthy, Richard Jones, Richard Betts and Mamdouh Antar

45 Mapping Areas Affected by Sea-Level Rise due to Climate Change in the Nile Delta Until 2100 Mohamed El Raey

46 Vulnerability of Tropical Montane Rain Forest Ecosystems due to Climate Change

Hans Juergen Bochmer

\section{Section B: Soil and Desertification}

47 Securitizing Land Degradation and Desertification: A Proactive Soil Security Concept Hans Günter Brauch and Úrsula Oswald Spring

Alternative Livelihoods for Attaining Sustainability and Security
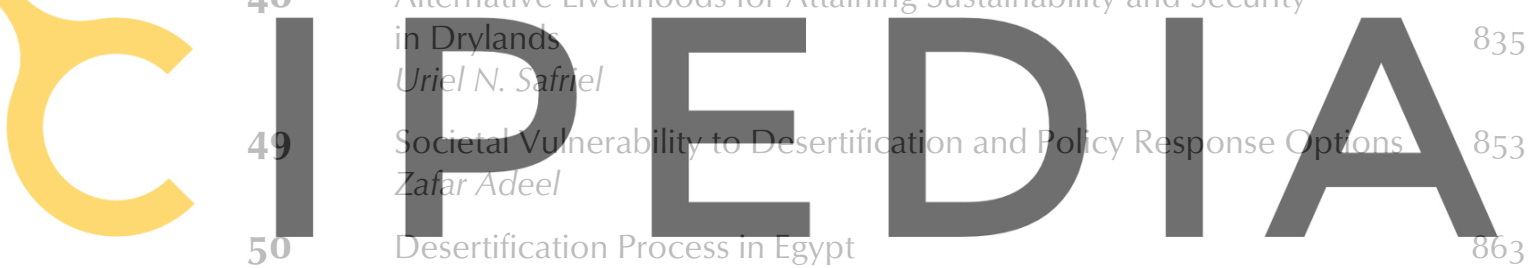

Ismail Abd El Galil Hussein

ister for free at https//www.scipedia.com to download the version without the watermark

51 Impacts of Drought on Agriculture in Northern Mexico

Tulio Arredondo Moreno and Elisabeth Huber-Sannwald

52 Traditional Knowledge in Coping with Desertification Pietro Laureano

53 Prodromes of Desertification in the Oasis of Tafilalet (Morocco) and Specific Local Solutions

Monique Mainguet, Frédéric Dumay, Lahcen Kabiri and Boualem Rémini

54 Agriculture in Drylands: Experience in Almeria Andrés Miguel García Lorca

55 Land-use Changes, Desertification, and Climate Change Impacts in South-eastern Spain Jorge García Gómez, Francisco López-Bermúdez and Juan Manuel Quiñonero Rubio 


\section{Section C: Water Management}

56 Reconsidering Integrated Water Resources Management: Promoting Economic Growth and Tackling Environmental Stress Jakob Granit

57 Coping with Population Growth, Climate Change, Water Scarcity and Growing Food Demand in China in the 21st Century Zhanyi Gao and Yaqiong Hu

$58 \quad$ Ensuring Water Security in Rural Areas of Bangladesh under Climate Change and Non-climatic Drivers of Change Mohammed Rahman Zillur and Kuntala Lahiri-Dutt

59 Applying Bottom-up Participatory Strategies and Traditional Methods of Water Harvesting in the Thar Desert, Rajasthan Kanupriya Harish and Mathews Mullackal

$60 \quad$ Coping with Water Scarcity in the Sahel: Assessing Groundwater Resources in the Western Sahel

Abdelkader Dodo, Mohamedou Ould Baba Sy and Jihed Channem

\section{Section D: Coping with Food Security Issues}

\section{Global Threats, Global Changes and Connected Communities in the} Global Agrofood System

John Grin and Esther Marijnen

\section{Genetically Modified Organisms: A Threat for Food Security and Risk}
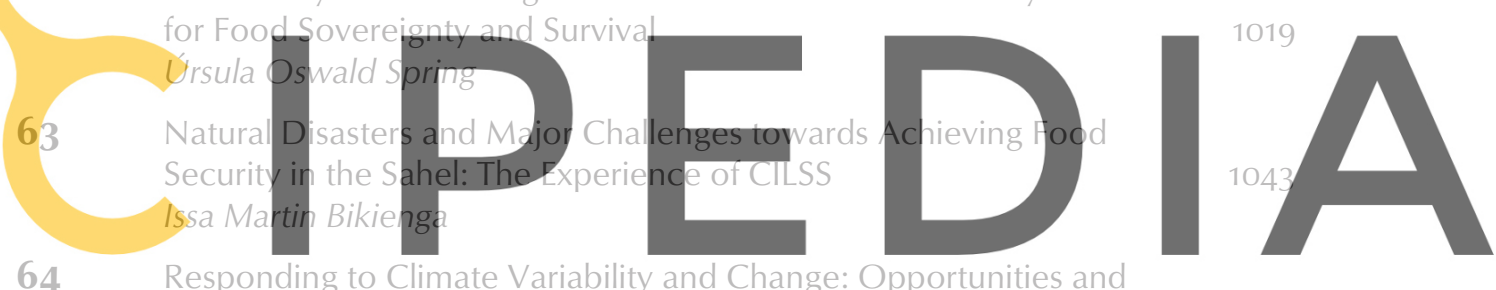

64. Responding to Climate Variability and Change: Opportunities and gister for free at htfphs

65 Coping with Climate Change Impacts on Coffee and Maize for

Peasants in Mexico 1067

Cecilia Conde

\section{Section E: Coping with Health Security Issues}

66 The Impact of AIDS on Women's Social Life in a Mexican Rural Community 1081 Fátima Flores and Wolfgang Wagner

67 Integrated Assessment of Vulnerability to Heat Stress in Urban Areas Tanja Wolf, Glenn McGregor and Anna Paldy 
Part VI Coping with Hazards and Strategies for Coping with Social Vulnerability and Resilience Building

68 Regulation and Coupling of Society and Nature in the Context of Natural Hazards Jörn Birkmann

69 Differentials in Impacts and Recovery in the Aftermath of the 2004 Indian Ocean Tsunami: Local Examples at Different Scales in Sri Lanka Katharina Marre and Fabrice Renaud

70 Risks in Central America: Bringing Them Under Control Juan Carlos Villagrán de León

71 Economics and Social Vulnerability: Dynamics of Entitlement and Access 1159 Koko Warner

72 Social Vulnerability, Discrimination, and Resilience-building in Disaster Risk Reduction

Úrsula Oswald Spring

\section{Part VIII Coping with Global Environmental Change: Scientific, International, Regional and National Political Strategies, Policies and Measures}

Section A: Scientific Research Goals and Strategies for Coping with Global Environmental Change

73

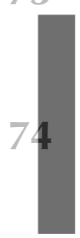
Coping with Global Environmental Change: Need for an
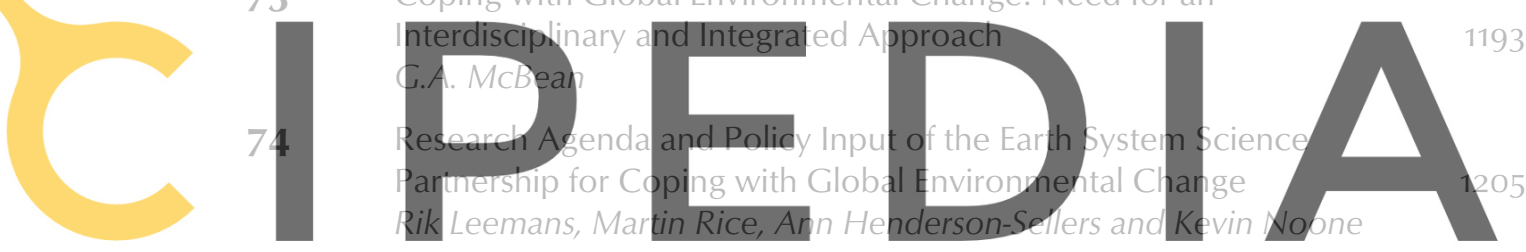

75 The International Human Dimensions Programme on Global gister for free at https//www.scipaediancomal to downtobidgtheckersian withtoutathe watermank21 Louise von Falkenhayn, Andreas Rechkemmer and Oran R. Young

76 DIVERSITAS: Biodiversity Science Integrating Research and Policy for Human Well-Being

Bruno A. Walther, Anne Larigauderie and Michel Loreau

77 The International Geosphere-Biosphere Programme's (IGBP) Scientific Research Agenda for Coping with Global Environmental Change Kevin J. Noone, Carlos Nobre and Sybil Seitzinger

78 Climate Information for Coping with Environmental Change: Contributions of the World Climate Research Programme John A. Church, Ghassem R. Asrar, Antonio J. Busalacchi and Carolin E. Arndt 


\section{Section B: Global Strategies, Policies and Measures for Coping with Climate Change}

79 Key IPCC Conclusions on Climate Change Impacts and Adaptations 1273 Martin Parry, Osvaldo Canziani, Jean Palutikof and Clair Hanson

80 Options for Mitigating Climate Change Results of Working Group III of the Fourth Assessment Report of the IPCC

Peter Bosch and Bert Metz

81 Global Climate Change, Natural Hazards, and the Environment: an Overview of UNESCO's Activities

Walter Erdelen and Badaoui Rouhban

82 Climate Change and Development: UNDP's Approach to Helping Countries Build a New Paradigm

Veerle Vandeweerd, Yannick Glemarec and Vivienne Caballero

\section{Section C: Regional Strategies, Policies and Measures for Coping with Climate Change}

83 EU Strategies for Climate Change Policy Beyond 2012 Christian Egenhofer, Arno Behrens and Anton Georgiev

84 Coping with Climate Change in East Asia: Vulnerabilities and

Responsibilities

Paul G. Harris

85 Strategies for Coping with Climate Change in Latin America: Perspective

beyond 2012

Ricardo Zapata-Martí

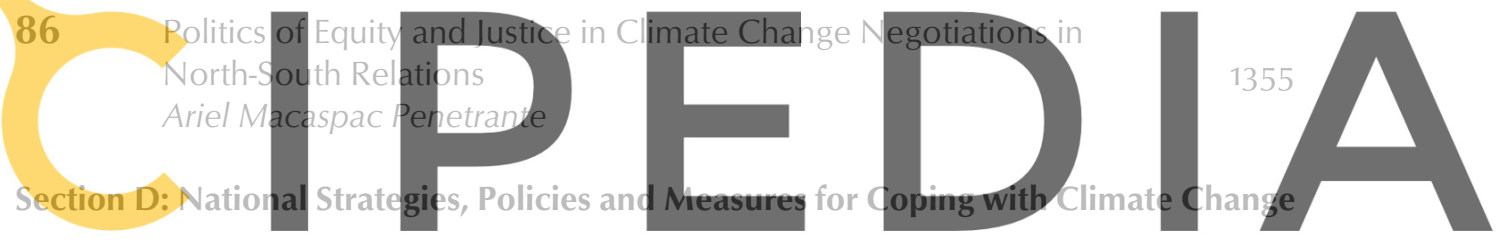

87 Climate Change: Long-Term Security Implications for China and the gister for free at https/7wwaw. Ecipediat.com to download the version without the watermark Yu Hongyuan and Paul J. Smith

88 Japanese Climate Change Policy: Moving Beyond the Kyoto Process 1381 Hiroshi Ohta

89 Implications of Equity Considerations and Emission Reduction Targets: Lessons from the Case of Japan's Mid-Term Target Norichika Kanie, Hiromi Nishimoto, Yasuaki Hijioka and Yasuko Kameyama 


\title{
$31 \quad$ Revealing the Impact of Small Disasters to the Economic and Social Development
}

\author{
Mabel C. Marulanda, Omar D. Cardona and Alex H. Barbat
}

\subsection{Introduction}

The effects of natural hazard events of small or moderate size are not considered by many people as 'disasters', although they share the same origins and causes of large and extensive effects. The impact of these events cannot be underestimated, because in general terms, they typify the disaster risk problem of a city, region or country. This chapter does not debate risk regarding to extreme events with a long return period, but insular, real and daily risk that multiple communities are exposed to in rural areas and in small and large cities. The most of these disasters are the result of socio-ecological processes associated with environmental deterioration and are associated with persistent small hazard events such as landslides, avalanches, flooding, storms, and also lower scale earthquakes and volcanic eruptions.

The analysis of small disasters illustrates how frequent small disasters, usually as a result of climate variability, increase difficulties for local development and entail a serious problem for the development of a country as a whole. These disasters, contrary to the extreme and extraordinary events, are very often not visible at the national level and their effects are not relevant from a macro-economic point of view. Small disasters usually affect the livelihoods of poor people in rural areas and small municipalities, perpetuating their level of poverty and human insecurity as factors of social vulnerability. In urban centres small and moderate disasters occur in those city zones that historically had the greatest degree of vulnerability.

At present, climate change impacts cause worry to several scientists and some politicians. Particularly the effects related to risk and human insecurity are increasing (UNFCCC 2007; UNDP 1994). However, the risk is growing not only from hazards due to climate variability that are exacerbated by climate change. There are also other risk factors that must be seen with the same thoroughness as the 'vulnerability' conditions and the need of 'adaptive capacity' to the action of the natural hazard events (IPCC 2007; Manuel-Navarrete/Gómez/Gallopin 2007). These are risk factors that have not been perceived well enough due to the lack of systematized information. For this reason, this chapter presents data that illustrate the increase of 'small disasters' or 'invisible disasters'. They are a result of climate variability and the vulnerability increasing from an economic, social, and environmental perspective. These figures illustrate, from a new perspective, that climate change implies a serious problem for disaster risk not only related to the potential of future extreme events but also small and frequent disasters that destroy the livelihoods of the poorest and deepen their incapacity of adaptation, perpetuating their vulnerability and poverty.

From the beginning of 1990's, some researchers in Latin America posed the hypothesis that the effects of small and moderate events, accumulated over time, could be equivalent and even bigger than the impact of big disasters. This hypothesis can be verified through analyses of the losses and damage reported in the DesInventar; database developed by the Social Network for Disaster Prevention in Latin America (La RED) and used in this research to evaluate the impact of small disasters This database has been useful to evaluate the number of events, the effects in terms of deaths, injuries, crops and housing destruction, the economic costs, and their comparison to the impact of extreme disasters.

The chapter presents the results of the evaluation of the proneness of Colombia to small scale and chronic disasters, and the type of impact they have for local development, and the country from an aggregated perspective. This analysis detected the spatial variability and dispersion of vulnerability and risk in the country as a result of events that rarely enter the international or even national disaster databases, but which pose an accumulative development problem for 
local areas and, given their overall probable impacts, for the country as a whole.

The empirical work made in Colombia to reveal the impact of small disasters in the country is treated in three sections. In the first, the database of small disasters used is described to identify the strengths and weaknesses of the available data and how that information was prepared for this research (3I.2). In the second, a conceptual framework regarding the impact of small disasters is presented to characterize the risk associated to this type of disasters (3I.3). In addition, in this section, a quantification of their effects and their economic costs are presented to illustrate their relevance due to their accumulated impact and recurrence. The third section presents the conclusions of the study (3I.4). They are not only concerning the specific case of Colombia but also other developing countries. Accordingly, new risk concepts have been issued (ISDR 2009): The concept of 'intensive risk' to refer to the concentrated risk manifesting infrequently in specific locations, and the concept of 'extensive risk' to refer to the diffuse risk manifesting frequently over wide territories.

\subsection{The DesInventar Disaster Database}

DesInventar ${ }^{1}$ offers simultaneously a database to elaborate a historical inventory of disasters and a methodology for their analysis. It consists of a software that allows to gather, systematize, organize, and consult information recorded in the system both from a spatial and temporal point of view, and an information capture and analysis methodology that especially emphasizes these aspects:

- DesInventar analyses disasters as a set of adverse impacts on lives, goods, infrastructure, and social relations caused by the interaction of socio-environmental and anthropogenic phenomena in given vulnerability conditions. It includes from those disasters very few effects (i.e. destruction of a house or five affected people because of crop loss caused by a frost) until those with large

1 Detailed information on the conception, methodology and use of DesInventar is at: 〈www.desinventar.org>, especially on the methodology and the user manual. The work by LA RED-OSSO for UNDP-ISDR on: "Comparative analysis of disaster database EmDat-DesInventar" of January 2003 may also be consulted at: <www.desenredando.org>. effects (such as the Quindío earthquake in Colombia, I999).

- Disasters materialize in communities and their environment. The scale of resolution of the observation of disasters affect the vision and understanding of them, therefore they should associate with various spatial scales, both to perceive small and 'invisible' disasters as an expression of daily risk construction, and to decompose those disasters that affect large areas with multiple and different effects that are singular for each affected community.

- Information that record the exposition, vulnerabilities, and risks conditions at all scales must be constructed as variables and indicators that should be as much as possible homogeneous both in terms of effects and in trigger effects. There should be a common language aiming at a compromise between rigorous definitions and the comparability of data at a continental scale.

- The resolution of the inventory offers information for the municipality or territorial level comparable with other countries. A local or regional inventory with a more detailed resolution can be made. This information is also gathered with a lower resolution (e.g. for a department or country).

DesInventar Colombia has been initiated, and maintained, refined and updated as a part of the Project DesInventar of La RED by the Observatorio Sismológico del Sur Occidente (OSSO) since 1994. It records information from I9I4 to 2002, with a total of 23,386 entries. The information used and analysed in this chapter covers a 32-year period (I97I-2002) and are based on 19,202 entries. In the databse DesInventar/Colombia, as in other existent disaster databases, the information compiled does not pretend to shape the universe of disasters that historically have occurred. In the best case, it is a wide sample of disasters, limited by the characteristics of the information and its sources, permanently subjected to debugs and complements and, therefore, it is not free of errors.

With regard to the sources three significant aspects can be distinguished in the case of Colombia:

a.) Until 1995, the principal source of database were newspaper archives, with an emphasis on national newspapers (El Tiempo and El Espectador) and, in some cases regional papers (La Patria of Manizales, El Colombiano of Medellin and Cali's). Irrespective of the quality of the information there is a bias in gathering information that privileges 
Antioquía, the coffee-growing zone, the Valle del Cauca and Bogotá/Cundinamarca, compared with other regions of the country. For other regions only cases are recorded that were reported in national newspapers ignoring the regional press. This implies that the quality of the recorded information on the regions is unequal.

b.) Since 1995, the main source has been provided by Disaster Prevention and Attention Directorate of Interior Ministry (DPAD), and has been complemented with information from the media. As the DPAD does not register 'all events' but only those which require national support, this information coverage is probably more significant for small and medium municipalities and for those departments with few resources (Costa Atlántica, Caquetá, Meta, Arauca, Casanare and Santanderes) than for big cities and the rest of the country, although press information contribute to reduce that slant.

c.) Information on national territories (e.g. Orinoquía and Amazonia with few inhabitants and very far from the national centre) is practically inexistent for this period.

d.) Due to the origin of information and representatives of sources, information on regional capitals and intermediate cities (bigger than 100,000 inhabitants in the census of 1993) is more complete than for the remaining municipalities).

In summary, weaknesses and problems with the data have been recognized and to some extent corrected or compensated for, as to be discussed on the next section. On the other hand, different factors must be considered for an appropriate analysis:

a.) It is important to have available strong or robust variables such as: type of the event that caused a disaster; date of occurrence and geographical location of the event. There are other less robust variables but useful for an analysis like number of dead people, number of destroyed and affected houses, and number of casualties and affected people as it results from the comparison with other databases, such as EmDat/DesInventar (La RED/OSSO 2003), that provide data on. The affected crop hectares can be also aggregated.

b.) In quantitative terms these less robust variables may present different problems (additional or generic 'prejudgment' of newspaper information) that require a permanent assessment of data and their analysis:
- The data from journalists often do not come from proven sources (and often contrast this information with other official sources of fire brigades, the red cross, civil defence, and 'technical and scientific' such as by Ingeominas (Colombian Institute of Geosciences and Mines) that produced studies or from other newspaper archives).

- Official sources that 'inflate' data due to certain political interests (e.g. the 'lathe operation' of the government (1994-I998) at the Atlantic Coast), are difficult to correct but may be compared with other non official sources.

- Errors in data compilations.

c.) Furthermore, not all entries contain the same information due to the type of damages (e.g. if there is no damage to houses but to bridges), or no quantification of them (a 'lot of damaged houses'), probably if the original information only includes certain variables and not others (e.g. logically, damaged houses must have a corresponding number of casualties or affected people, although they do not belong to anybody and nobody lives there, and it does not always appear).

d.) Particularly the affected people often include high numbers that in 99 per cent of cases refer to the inclusion of the affected population that stayed one or two hours, or one or two days without supply of basic services (e.g. two million people lacked electricity in Bogotá).

e.) From a spatial perspective, as the information is organized by municipalities, three problems may occur: a) some records are taken at regional level and municipality is not defined; b) some records are taken at a lower municipal level (commune, road); and c) some municipal divisions change and it is not possible to know which records correspond to which municipality.

\subsubsection{Preparation of the Database}

Information was compiled based on 19,202 records for 1971-2002 reflecting limitations mentioned above. After a validation of the data based on these criteria these variables were analysed:

1. For affected people, data from a suspension of public services $(\mathrm{I}, 500,000$ affected people in Medellín due to a power blackout for two hours, for example) were excluded.

2. A value for affected people was given to entries on destroyed or affected houses. These estimates 
tried to be conservative assuming that only one family lived in each destroyed or affected house.

3. Given the disparity of criteria for differentiating between casualties and affected people, it was assumed that both cases (except for those referred to above) were about direct effects of diverse scales or intensity and therefore they were integrated in one variable.

4. Other detected problems dealt with the geographical location of an event and computation errors were corrected.

5. The used database includes an assessment and complementation by La RED/OSSO. This has been useful not only for this study but also for other ongoing research with the Inter-American Institute for Weather Change (IAI) and the Programme of Disaster Risk Management Indicators of the Institute of Environmental Studies of the Inter-American Development Bank (IDB-IDEA).

After the database was updated and adjusted the information was analysed to confirm the relevance of small and moderate disasters and their accumulated impact compared with extreme events from 1970 to 2002, and for all municipalities where effects of the impact of local disasters were recorded. A hypothesis is that the effects from small and moderate events, accumulated over time, could be equivalent and even bigger than the impact of big disasters (La RED). This hypothesis can be verified through analyses of the losses and damage reported in the DesInventar database. However, some requirements are desirable, namely:

a.) Information in available records is incomplete. The sources of information do not always include damage or loss values. In many entries some variables are only expressed qualitatively (e.g. approximately 35 per cent). In some cases numbers are recorded, but in other cases only general effects were noted).

b.) As the information on the entries is not homogeneous, only damages and loss categories are considered for the number of deaths, affected (injured) people, destroyed houses and the number of affected crop hectares.

c.) These data cannot be considered as definitive; they are approximated, and only compare effects with reported damage and losses of big disasters. d.) This analysis has focused only on small and moderate events excluding figures on big disasters.

e.) Given the type of information, analysis of damage and loss accumulation from small and moderate events is compiled for the national level.

Throughout these 32 years Colombia was affected by several local events that oscillated between small and moderate (table 3I.I).

Table 31.1: Number of small and medium disasters in Colombia (1971-2002). Source: DesInventar database, La RED (2004).

\begin{tabular}{|c|c|c|}
\hline Period & $\begin{array}{c}\text { Number of } \\
\text { events }\end{array}$ & $\begin{array}{c}\text { Percentage of } \\
\text { total }\end{array}$ \\
\hline $1971-1980$ & 5,226 & 27.2 \\
\hline $1981-1990$ & 5,405 & 28.1 \\
\hline $1991-2000$ & 7,063 & 36.8 \\
\hline $2001-2002$ & 1,508 & 7.9 \\
\hline $\mathbf{1 9 7 1 - 2 0 0 2}$ & $\mathbf{1 9 , 2 0 2}$ & $\mathbf{1 0 0}$ \\
\hline
\end{tabular}

\subsection{Small and Moderate Disasters}

Disaster implies loss and damage and subsequent impacts that the affected community is unable to absorb or to cushion the effects and recover using its own resources and reserves. The concepts of vulnerability, or predisposition to be affected, and resilience, or capacity of recovery and adaptive behaviour, enter to play an important role due to their significant relation with the possible occurrence of disasters. Hence, disaster is a social context or process, triggered by a natural, technological or anthropogenic phenomenon, which in interaction with a susceptible medium causes intense alterations in the normal functioning of the community. Regarding disasters some processes require special attention. These include population growth, rapid urban development, international financial pressures, degradation of the earth, global warming, and environmental change and war. To take but a limited number of examples, urbanization processes have been an important factor in damage caused by earthquakes in urban areas; population increase helps to explain increases in the number of persons affected by floods and prolonged droughts; and deforestation increases the chances of flooding and landslides (Wisner/Blaikie/Cannon/Davis 1994; Birkmann 2006). Adhering to the hypothesis that the lack of development and vulnerability are correlated, and considering that the lack of capacity to cope, recover, and adapt is 
also a factor of vulnerability, particularly taking into account the climate variability and change, Cardona (chap. 3) suggests that vulnerability originates in physical fragility or exposure; the social, economic, and ecological fragility; and the lack of resilience or ability to cope and recover. Seen from this human or social perspective, any understanding of vulnerability also requires careful consideration of the factors or contexts that contribute to human and livelihood vulnerability: the security or insecurity of buildings, infrastructure, and environment; the nature of institutions and social organizations; the levels of income and welfare, etc. These explicatory factors do then become a fundamental part of the equation and understanding of human or social vulnerability.

Risk regarding small disasters usually is not considered as relevant, nevertheless small disasters are a social and environmental problem with big implications. These events are primarily related to persistent hazards such as landslides, avalanches, floods, forest fires, droughts, and so on resulting from socio-ecological processes associated with climate variability and environment deterioration that affect, in a chronic way, the most fragile socio-economical low-income population in rural as well as in urban areas. In general, small and frequent disasters prevent the sustainability of local human development and they reveal in which areas of urban centres the vulnerability is growing and where new hazards or the exacerbation of the already existing hazards are occurring due to inadequate environmental, social, and economic processes.

Taking into account the abovementioned and the report of Marulanda/Cardona (2006) the concept of intensive risk refers to concentrated risk manifesting infrequently in specific locations and the concept of extensive risk refers to diffuse risk manifesting frequently over wide territories (Maskrey 2008). Global disaster databases and risk indexes reflect principally patterns of intensive risk given that extensive risk is largely invisible from a global level of observation. $E x$ tensive risk patterns only become visible from a national level of observation and a higher resolution, and thus have consistently been ignored. Due to this invisibility extensive risk has not been a driver of disaster risk reduction, which has focused primarily on saving lives and mitigating against major economic loss. A central hypothesis of the ongoing 2009 ISDR Global Assessment Report on Disaster Risk Reduction is that whereas mortality and economic loss risks tend to be intensive, asset risks in sectors such as housing and agriculture are more extensive in character and have pervasive, negative impacts on the liveli- hoods and lives of poor urban and rural populations. Through testing this hypothesis the Global Assessment Report will make the case for strategies to address extensive risk to become central to both disaster and poverty reduction, as well as to climate change adaptation.

Small and moderate disaster analysis, and the definition of large events, create diverse methodological problems, especially two: a) the problem of a threshold from which a disaster is considered as large, and b) given the effects of an event (e.g. an earthquake) on different territorial units, which of these effects should be included or excluded in an analysis of small and moderate disasters, given the singular impacts registered in each unit (i.e. a municipality alone ${ }^{2}$ ). Without pretending to have an answer to these two problems, the analysis should be inclined to exclude from the database the information of effects related to large disasters. Taking into account the preparation of the database and the difficulties to identify all potential wrong data by a detailed analysis and, particularly, the shortcomings due to several disputed figures of affected people and affected hectares of crops, an outlier (or an extreme value) identification process defining arbitrary thresholds was applied. Although the direct selection of large disasters is an acceptable procedure, the definition of a large disaster is a problem if a systematic approach is attempted. The process of identification of outliers ${ }^{3}$ detected the extreme main effects of large hazard events, but their small or moderate effects were considered and the selection should be based on the size of the effects and not because the effects were made by a 'recognized' hazard event.

\subsubsection{Effects Caused by Small and Moderate Disasters}

In Colombia, for the period from I97I to 2002, the emergency database (EM-DAT) by the Centre of Epi-

2 The DesInventar database contains the information of effects by municipality and not by event.

3 Outliers are obtained using statistical and data mining techniques. Criteria for extreme values were chosen, taking into account when the value in each case could be considered as very large. This means, that the effects in a municipality are considered extreme when they are usually visible or notable at the national level. The values considered as extremes are the following: Dead people: more than 500 people; Injured people: more than I,500 people; Affected houses: more than 4,500 houses; Destroyed houses: more than 2,500 houses; and Destroyed crop hectares: more than 80,000 hectares. 
Table 31.2: Gross figures of effects as a result of small and moderate disasters. Source: Des/nventar database, La RED (2004).

\begin{tabular}{|c|c|c|c|c|c|}
\hline Period & Deaths & Affected & $\begin{array}{l}\text { Destroyed } \\
\text { houses }\end{array}$ & $\begin{array}{l}\text { Affected } \\
\text { houses }\end{array}$ & $\begin{array}{c}\text { Damaged crop } \\
\text { hectares }\end{array}$ \\
\hline 1971-1980 & 2,964 & 204,393 & 18,588 & 16,604 & 327,497 \\
\hline 1981-1990 & 3,812 & 608,180 & 19,754 & 16,044 & 738,743 \\
\hline 1991-2000 & 2,394 & 871,374 & 50,465 & 163,051 & 964,450 \\
\hline 2001-2002 & 305 & 61,584 & 4,353 & 21,376 & 144,023 \\
\hline 1971-2002 & 9,475 & $1,745,531$ & 93,160 & 217,075 & $2,174,713$ \\
\hline
\end{tabular}

Table 31.3: Effects per local event on average. Source: DesInventar database, La RED (2004).

\begin{tabular}{|l|c|c|c|c|c|}
\hline Period & Death & Affected & $\begin{array}{c}\text { Destroyed } \\
\text { houses }\end{array}$ & $\begin{array}{c}\text { Affected } \\
\text { houses }\end{array}$ & $\begin{array}{c}\text { Damage crop } \\
\text { hectares }\end{array}$ \\
\hline $1971-1980$ & 0.57 & 39.11 & 3.56 & 3.18 & 62.67 \\
\hline $1981-1990$ & 0.71 & 112.52 & 3.65 & 2.97 & 136.68 \\
\hline $1991-2000$ & 0.34 & 123.37 & 7.14 & 23.09 & 136.55 \\
\hline $2001-2002$ & 0.20 & 40.84 & 2.89 & 14.18 & 95.51 \\
\hline $1971-2002$ & 0.49 & 90.90 & 4.85 & 11.30 & 113.25 \\
\hline
\end{tabular}

demiology of Disasters of the Catholic University of Louvain (chap. 40 by Guha-Sapir), lists at present 97 events that fulfil at least one of these criteria: a) Io or more dead people; b) at least Ioo affected people; c) emergency state has been declared; and, d) international assistance has been required. Summarizing, it is about events that in some way have attracted the attention of authorities or news reports. That is, it deals with visible disasters. However, beyond these notable disasters, there are hundreds, even thousands of events that occurred in the same period which were not listed in these statistics of international organizations on this subject. According to the DesInventar database in Colombia more than 19,000 events occurred during the same period. This number of events contrasts considerably with 97 events listed by the EM-DAT disaster database. Therefore, a gross assessment of damages and losses caused by small and moderate events in Colombia from I97I to 2002 using the DesInventar indicates that they have not been marginal. Table 3I.2 shows that close to 9,500 dead people, almost 2 million affected people, 93,000 destroyed houses and 217,000 affected houses, as well as close to 2 million destroyed crop hectares were the result of an accumulation of this type of disasters.

During the 1990's, there is both an accumulation trend of larger number of effects and greater records of occurred small disasters. In this period, with exception of the number of death people, the largest damages and losses occurred. They have been much big- ger than the average registered by local events during the 32 years studied, as is illustrated by table 3I.3.

In table 3I.3, the last line shows the overall average values for the whole studied period. The losses and damages related to death people, affected people and destroyed crop hectares of decade I98I-I990 were above average of the period of 32 years, while for the period between I97I and 1980 only the number of death people by event were above the average of the whole period. A comparison of annual averages for the three decades and for 200I-2002 shows that the latter offers very high values for only two years against periods of ten years.

As the quality of data are similar since the 1970's, the trend towards an increase in the amount of damage and losses by small disasters throughout these years can only be explained by two factors: first, the growing of the intensity and recurrence of hazard events; second, the increasing vulnerability and volume of exposed elements. The rise of hazard events is detected particularly in some hydrographic basins resulting from the environmental degradation and perhaps due to the gradients of climate variability (i.e. climate change). Taking the growing population and urbanization during the past 40 years into account, a growth in the volume of exposed elements and in their vulnerability can be observed. In any case, it can be argued that the increase and accumulation of risks in Colombia are consequences of rising natural and socio-natural hazard events that are due to the devel- 
opment model the country has implemented and maybe due to climate change.

In comparative terms, the accumulation of damage and losses induced by small disasters during the whole period is notable. If they are compared with the biggest disasters Colombia suffered during the past 32 years - i.e. the Nevado del Ruíz volcanic eruption in 1985 and the Quindío earthquake in 1999 - the figures cannot be undervalued as shown in table 3I.4.

Table 31.4: Comparison between the effects due to small and extreme disasters: Sources: DesInventar database, La RED (2004), and report on small disasters for National Department of Planning, ERN-Colombia (2005).

\begin{tabular}{|l|c|c|c|}
\hline $\begin{array}{l}\text { Type of } \\
\text { damages } \\
\text { and losses }\end{array}$ & $\begin{array}{c}\text { Nevado del } \\
\text { Ruíz erup- } \\
\text { tion (1985) }\end{array}$ & $\begin{array}{c}\text { Quindío } \\
\text { Earthquake } \\
\mathbf{( 1 9 9 9 )}\end{array}$ & $\begin{array}{c}\text { Small } \\
\text { disasters } \\
\text { (1971-2002) }\end{array}$ \\
\hline $\begin{array}{l}\text { Deaths of } \\
\text { people }\end{array}$ & 24,442 & 1,862 & 9,475 \\
\hline $\begin{array}{l}\text { Affected } \\
\text { people }\end{array}$ & 232,546 & 160,336 & $1,745,531$ \\
\hline $\begin{array}{l}\text { Destroyed } \\
\text { houses }\end{array}$ & 5,402 & 35,949 & 93,160 \\
\hline $\begin{array}{l}\text { Affected } \\
\text { houses }\end{array}$ & $\mathrm{NA}$ & 43,422 & 217,075 \\
\hline $\begin{array}{l}\text { Damage of } \\
\text { crop hectares }\end{array}$ & 11,000 & $\mathrm{NA}$ & $2,174,713$ \\
\hline
\end{tabular}

Although the number of deaths in the volcanic disaster of 1985 represents an extraordinary event that exceeded predictions of any specialist at that time, the accumulation of deaths caused by small disasters over time also tend to be an elevated figure. It represents 38.8 per cent of the deaths that occurred in Armero and Chinchina through the volcanic eruption. The number of affected people from small disasters is 7.5 times those of large disasters, and this amounts to almost II times the figure of the Quindío earthquake of 1999 which severely affected the whole coffeegrowing region. Taking the total of destroyed houses into account, the figure for small disasters represents more than 2.5 times the total of destroyed houses in the Quindío earthquake and more than I7 times the destroyed houses in Armero and Chinchina. The houses affected by small disasters are 5 times as high as those for the Quindío earthquake.

\subsubsection{Economic Cost of Small and Moderate Disasters}

In terms of economic cost the recorded losses from small and moderate local events are very significant. If two categories of economic losses (damaged houses and crop hectares) are considered, the total amount accumulated for 32 years of study exceeds I,650 million dollars according to table 3I.5 of this total, 35.I per cent corresponds to the amount of destroyed and affected houses and the other part (64.9 per cent) corresponds to the amount of damage from crop hectares.

Table 31.5: Estimated cost of losses and damage caused by small disasters, in 1,000 US\$. Source: Based on the methodology of the IDB-IDEA Programme of Indicators, IDEA (2005a/b).

\begin{tabular}{|l|r|r|r|}
\hline Period & \multicolumn{1}{c}{$\begin{array}{c}\text { Losses in } \\
\text { houses }\end{array}$} & \multicolumn{1}{c|}{$\begin{array}{c}\text { Losses in } \\
\text { crops }\end{array}$} & \multicolumn{1}{|c|}{ Total } \\
\hline $1971-1980$ & $68,217.00$ & $98,249.10$ & $166,466.10$ \\
\hline $1981-1990$ & $78,424.50$ & $295,497.20$ & $373,921.70$ \\
\hline $1991-2000$ & $385,892.33$ & $578,669.70$ & $964,562.03$ \\
\hline $2001-2002$ & $47,127.42$ & $100,816.45$ & $147,943.87$ \\
\hline $1971-2002$ & $579,661.25$ & $1,073,232.45$ & $1,652,893.70$ \\
\hline
\end{tabular}

This approximation is useful for estimating the magnitude of losses and to make general comparisons. ${ }^{4}$ Although in the case of affected crops overestimates are possible due to the valuation of errors or to the difficulty of estimating the real surface affected, it can easily be observed that losses in the agricultural sector are very important, although they are hardly visible.

These are hypothetical values and they neither correspond with real reconstruction expenditures nor to any coverage of losses made by the government. The value of any destroyed house is assumed as the average cost of a social housing unit according to the ex-

4 Methodology proposed by the Risk Indicators Project IDB-IDEA was applied for calculation of losses caused by small disasters. In the case of houses, the total of destroyed houses plus affected houses, where 4 affected houses correspond to a destroyed house has been considered. Estimation of loss is made assuming reconstruction a social interest house (average number of square meters by value of square metre constructed of this type of construction in each period) and without the cost of land. For the case of the loss estimation of crops, it was obtained based on the average cost of the typical hectares of crops in the flooded zones by total number of affected hectares. 
isting standards in each country (number of square meters) during the period of analysis. And, the value per square meter of social housing is equivalent to one legally established minimum salary during the same time period. On the other hand, it is proposed that the value of one hectare of crops be calculated on the basis of the weighted average price of usually affected crop areas, taking into account expert opinion in the country at the time of analysis. In most of cases, neither any formal reconstruction programme was made nor any government loans or subsides for reconstruction or recovering have been paid to the affected people. Although these estimates are not accurate, the figures refer to the magnitude of a problem that is worrying and often overlooked. Most affected people come from low-income communities with scarce resources that do not receive any recovery aid from the government when this type of events occurs. In addition, they are recurrently affected by these small disasters at the local level, losing their livelihoods. While this chronic situation may not be relevant from a macroeconomic point of view, it perpetuates their poverty and the underdevelopment of the country. This is a worrying situation as the adaptive strategies of low-income communities are less effective and unsuccessful at present, and because disaster resilience is now diminished to cope with the effects of climate change and climate variability.

Based on the data in tables 3I.2 and 3I.5 it can be clearly observed that the losses have grown over time in a different way if they are compared with the respective number of events. Thus, between the 1970's and 1980's the number of events grew only by 3.42 per cent but the losses occurred had an unexpected increase of 224.6 per cent. Whereas the increase of events from the I980's to I990's was 130.68 per cent, the losses had an extraordinary growth of 257.96 per cent. The importance of these figures expressed in monetary terms can also be seen if the average cost of each recorded event is considered. The average cost for each event for the decade of I97I to I980 amounted to US\$ 31,853 , for the period from I98I to 1990 it was US\$ 69,I8I, and for I99I to 2000 it was US\$ 136,566 .

A comparative analysis of losses caused by small events and some of the recognized extreme disasters with the massive destruction that have occurred in Colombia is useful to assess the impact that small and moderate events have had over time. According to figures of table 3I.6, the material losses in current million US $\$$ caused by small disasters during 32 years are 6.7 times the losses caused by the Nevado del Ruíz volcanic disaster in 1985. Even the aggregated losses during the decade (I98I-I990) due to small disasters are I.5 times the losses caused by the same disaster in Armero and Chinchina.

Table 31.6: Losses of extreme hazard events, in current million dollars and in percentage of GDP. Source: Extreme events, report on small disasters for National Department of Planning, ERN-Colombia (2005).

\begin{tabular}{|l|r|r|}
\hline Events & \multicolumn{1}{c|}{$\begin{array}{c}\text { Estimated } \\
\text { losses }\end{array}$} & $\begin{array}{c}\text { Costs of } \\
\text { rehabilitation }\end{array}$ \\
\hline $\begin{array}{l}\text { Eruption of Ruíz Volcano } \\
\text { (1985) Armero }\end{array}$ & $246.05(0.70)$ & $359.95(1.02)$ \\
\hline $\begin{array}{l}\text { Coffee Region Earth- } \\
\text { quake (1999) Quindío }\end{array}$ & $1,590.81$ & $856.72(1.01)$ \\
\hline $\begin{array}{l}\text { Small and moderate } \\
\text { events (1971-2002) }\end{array}$ & $1,652.89$ & NA \\
\hline
\end{tabular}

NA: It means not available data, but, in most cases, direct investments from State have not been made.

The total of losses from small local events surpassed the material losses caused by the Quindío earthquake in 1999 when the figures of destroyed houses and crop hectares are considered. This means that approximately for every 30 years, the losses from small disasters to housing and agriculture are similar to the losses produced by a large event such as the Quindío disaster. The big difference between the extreme and small disasters mentioned above is that in the first case, any programme of reconstruction has been implemented and significant investments have been made to aid the affected people, whereas in the second case no formal rehabilitation or reconstruction activities have been implemented. This means that people affected by small disasters only in some cases received humanitarian aid but in all cases they did not receive any substantial post-disaster aid for recovery and development.

Nowadays estimates of the economic impact of disasters are very common taking aggregated macroeconomic variables into account, such as the gross domestic product (GDP). This has been the approach of the International Financial Institutions as well as of the banks and agencies as the Economic Commission for Latin America and the Caribbean (ECLAC). Although it is recognized that the economic losses do not correspond to the real impact of disasters, the economic losses expressed as a percentage of national and sectoral GDP's are certainly useful to illustrate the relevance of small disasters and their impact for 
Table 31.7: Accumulated losses of small disasters in million US $\$$ and percentage of the agricultural GDP. Source: For the estimate the GDP of the last year of each period was taken using data by the Word Bank (2003).

\begin{tabular}{|l|r|r|r|}
\hline Period & $\begin{array}{c}\text { Losses in crops in current } \\
\text { (constant) US\$ }\end{array}$ & $\begin{array}{c}\text { GDP agricultural sector in } \\
\text { current (constant) US\$ }\end{array}$ & $\begin{array}{c}\text { Losses in sectoral GDP } \\
\text { (percentage) }\end{array}$ \\
\hline $\mathbf{1 9 7 1 - 1 9 8 0}$ & $98,25(172.64)$ & $6,466(11,352)$ & 1,52 \\
\hline $\mathbf{1 9 8 1 - 1 9 9 0}$ & $295,50(689.50)$ & $6,539(15,257)$ & 4,52 \\
\hline $\mathbf{1 9 9 1 - 2 0 0 0}$ & $578,67(758.38)$ & $10,330(13,358)$ & 5.60 \\
\hline $\mathbf{2 0 0 1 - 2 0 0 2}$ & $100,82(138.80)$ & $10,103(13,909)$ & 1.00 \\
\hline $\mathbf{1 9 7 1 - 2 0 0 2}$ & $1,073.24(1,759.32)$ & $(13.909)$ & $(12.65)$ \\
\hline
\end{tabular}

Table 31.8: Accumulated losses from small disasters in million US\$ and percentage of construction GDP. Source: For estimates, the GDP was taken of the last year of each period using data of the Word Bank (2003).

\begin{tabular}{|r|r|}
\hline Period & $\begin{array}{r}\text { Losses in housing in } \\
\text { current }(\text { constant) US\$ }\end{array}$ \\
\hline $1971-1980$ & $68.22(119.87)$ \\
\hline $1981-1990$ & $78,42(182.98)$ \\
\hline $1991-2000$ & $385.89(505.73)$ \\
\hline $2001-2002$ & $47.13(64.88)$ \\
\hline $1971-2002$ & $579.66(873.47)$ \\
\hline
\end{tabular}

$\begin{array}{rr}\begin{array}{c}\text { GDP construction sector in } \\ \text { current (constant) US\$ }\end{array} & \begin{array}{r}\text { Losses in sectoral } \\ \text { GDP }(\%)\end{array} \\ 1,607.20(2,824.11) & 4.25 \\ 1,993.10(4,650.58) & 3.95 \\ 3,058.10(4,007.80) & 12.62 \\ 3,184.95(4,354.89) & 1.48 \\ (4.354 .89) & (19.92)\end{array}$

Table 31.9: Accumulated losses of small disasters in million US $\$$ and percentage of GDP of Colombia. Source: For estimates, the GDP was taken of the last year of each period using data of the Word Bank (2003).

\begin{tabular}{|l|r|r|r|}
\hline Period & $\begin{array}{c}\text { Losses [crops+houses] } \\
\text { current (constant) US\$ }\end{array}$ & $\begin{array}{c}\text { National GDP in } \\
\text { current (constant) US\$ }\end{array}$ & $\begin{array}{r}\text { Participation of losses in } \\
\text { per cent of national GDP }\end{array}$ \\
\hline $1971-1980$ & $166.47(264.81)$ & $33,400(53,180)$ & 0,50 \\
\hline $1981-1990$ & $373.92(688.05)$ & $40,274(74,108)$ & 0,93 \\
\hline $1991-2000$ & $964.56(1,129.24)$ & $83,220(96,652)$ & 1,16 \\
\hline $2001-2002$ & $147.95(175.94)$ & $84,002(99,893)$ & 0,18 \\
\hline $1971-2002$ & $1,652.89(2,249.03)$ & $(99,893)$ & $(2.25)$ \\
\hline
\end{tabular}

the national economy. In the agriculture sector, for example, small disasters recorded elevated amounts of losses. Table 3I.7 shows accumulated losses for the period I97I-I980 that were equivalent to I.52 per cent of the agricultural GDP for 1980. Furthermore, the impact of small disasters was more significant for the I980's because the total amount of losses in the sector represented 4.52 per cent of the agricultural GDP for I990; and it was greater ( 5.6 per cent) for the I990's. Losses in the sector have been equivalent to $\mathrm{I} 2.65$ per cent of sectoral GDP, constant prices, for the period of 32 years. It is important to say the agriculture is one of the most important sectors of the country's economy.

Table 3I.8 shows losses due to the destruction of housing by small disasters in terms of GDP for the construction sector. The amount of losses is consider- ably smaller than recorded in the agricultural sector, but the impact on the sectoral GDP is quite larger. During the I970's the losses were equivalent to 4.25 per cent of the construction GDP. In the I980's it was 3.95 per cent and in the I990's losses rose to I2.62 per cent. In accumulative terms, damages for housing during the 32 years represented $19.92 \%$ of GDP, at constant prices, in the construction sector. This is another important sector of the economy and employment source in Colombia.

Finally, at an aggregated level, the impact of small disasters has been significant. According to table 31.9, the total of losses for the construction and agricultural sector caused by small disasters during the period of 32 years represents 2.25 per cent of the national GDP for 2002, in constant prices. This is significant taking into account that losses caused by the 
Quindío earthquake represented I.88 per cent of the national GDP of 1999.

Given these figures for small disasters, it is difficult to refer to disasters without any impacts; furthermore among the estimated losses the cost of damage for the infrastructure (i.e. lifelines, facilities, roads, bridges, etc.) and for productive sectors (industry, commerce, electricity and others) were not included.

These figures are not only significant in quantitative terms but they offer evidence that confirms the hypothesis that recurrent and accumulated effects of damage and losses by small disasters can be equivalent and in many cases even larger than by those caused by extreme disasters, whose correlation or simultaneousness of effects are very visible. Even though these small disasters continue to remain 'invisible' and they are not considered as events of concern. The data that were given above illustrate the relevance of these disasters, because they indeed represent a worrying risk situation that exists in all Latin American countries.

\subsection{Conclusions}

The experience with the application of DesInventar for other Latin American and Caribbean countries has given extremely positive results when a wide view is used of the type of events that most frequently appear in these countries. So far the Colombian case study represents the most complete effort to apply this tool and the deepest analysis because it has not only allowed to describe the frequent types of disasters affecting the country, but also to identify in some cases their causes and effects, the high priority attention zones, and the impact small disasters have caused for the economy of specific sectors and at the national level as well.

Small disasters are usually not very relevant from macroeconomic perspective because they are usually not important for contingent liabilities and for fiscal sustainability of a country; this is the reason why they are very often ignored. However, small disasters are certainly relevant from social and microeconomic point of view and; therefore, they should not be ignored by the policy makers and planners.

The main objective of this chapter has been to analyse the results of an evaluation of the proneness of Colombia to small scale and chronic disasters, and the type of impact they have on the local development and for the country from an aggregated perspective. This analysis has detected the spatial variability and dispersion of risk due to events that are rarely recorded in international or national disaster databases, but which pose serious and accumulative development problems for local areas given their probable overall impacts for the country as a whole. In addition, the growing number of small disasters and their effects illustrate that the adaptive strategies of poor communities are less effective now as result of the recurrent destruction of their livelihoods, and due to the reduction of human settlements disaster resilience. Most of these disasters are the result of socioecological processes associated with the environmental deterioration and are associated with persistent small events such as landslides, avalanches, flooding, storms, and also lower-scale earthquakes and volcanic eruptions.

With these results it is possible to stress that extreme disasters not necessarily determine the history of disasters. Until now in Colombia the recent history has been dominated by big disasters such as those caused by the Popayan earthquake (1983), the Nevado del Ruíz eruption (I985), the Tierradentro (Paez) earthquake (1994) and the Quindío earthquake (1999). By accepting the relevance of their effects on the population and the economy as a whole, it must also be recognized that each year many small and moderate disasters, that individually do not cause high damages and losses, affect the population and the diverse economic sectors due to their frequency and their accumulated impact over time.

The outcomes of this analysis has been useful for economic analysts and sectoral decision-makers responsible for urban policy development, because they can detect not only the potential impact of extreme events but also the persistence and accumulation of effects of small and local disasters. This stimulates the consideration of risk problems in territorial planning at the local level, the intervention and protection of hydrographic basins, the protection of ecosystems, and the implementation of resource transfer and collective insurance programmes to cover the losses of poor communities. This research reveals that the aggregated impact of small disasters as well as the impact of extreme events also leads to a fiscal exposure and contingent liability for the government to compensate housing and to recover the livelihoods of the poorest people. 